\title{
ВЕБ-ДОДАТОК ДЛЯ МАРКЕТИНГОВОГО АНАЛІЗУ СОЦІАЛЬНОЇ МЕРЕЖІ INSTAGRАМ
}

Розроблено веб-додаток для маркетингового аналізу бізнес-акаунтів соціальної мережі Instagram, який дає змогу в реальному часі отримувати достовірну інформацію про поточний їхній стан, нарощувати аудиторію потенційних користувачів через автоматизацію певних дій, а також уможливлює формування стратегій подальшого їх просування. Встановлено основні потреби аналізу соціальної мережі Instagram, що дало змогу маркетологам розробити комплекс заходів для просування бізнес-акаунтів через запровадження відповідних медіа-ресурсів. З'ясовано причини застосування Instagram-метрик, статистик і автоматизації дій користувача для аналізу маркетингової інформації, що дало змогу визначити параметри поточного стану бізнес-акаунта і розробити стратегії для подальшого його просування.

Спроектовано архітектуру веб-додатку для реалізації метрик, статистик і автоматизацій дій користувача, що дало можливість розробити відповідний програмний засіб для маркетингового аналізу соціальної мережі Instagram в реальному часі, який забезпечує отримання достовірної інформації про поточний стан бузнес-акаунта. Розроблено структуру організації баз даних для реалізації веб-додатку, який забезпечує надійне зберігання даних, необхідних для авторизації та автоматизації дій користувача, а також обчислення відповідних метрик і статистик, підготовки певних компонент - клієнтів для доступу до цих баз даних, застосовуючи первинні та вторинні індекси для підвищення ефективності виконання запитів до них. Реалізовано веб-додаток з використанням відповідної технології та мови програмування у певному середовищі розробки, а також систему управління базами даних. У структуру його реалізації імплементовано такі функціональні характеристики, як аналіз бізнес-акаунта на підставі метрик і статистик, налаштування автоматизації таких дій користувача, як стеження за іншими користувачами, вподобання та коментування їхніх дописів у мережі Instagram.

Ключові слова: бізнес-акаунт; медіа-ресурси; аудиторія потенційних користувачів; стратегія просування акаунту; маркетингова інформація; архітектура веб-додатку; реалізація метрик і статистик; автоматизація дій користувача.

Вступ. Соціальна мережа - це веб-сервіс у вигляді віртуального співтовариства, безпосередні користувачі якого мають подібні інтереси, нахили, мотиви, плани, професійні наміри та індивідуальні розваги (Bashinskaуа, 2012). За словами В. М. Сазонова (Danko, 2012), під соціальною мережею розуміють множину акторів, які можуть взаємодіяти між собою через соціальні зв'язки дружбу, спільну діяльність або обмін інформацією. Вважають (comScore, 2019), що перша соціальна мережа з'явилась у 1995 р., коли нову сторінку відкрив американський сайт Classmates.com, який пропонував відновити контакти з однокласниками, друзями та родичами. Однак офіційним початком появи соціальних мереж прийнято вважати 2003-2005 роки, коли були запущені LinkedIn, MySpace, Facebook i YouTube (Barabasi, 2002). На сьогодні багато соціальних мереж переживають справжній бум популярності, який розпочався у 2009 2011 роках завдяки збільшенню швидкості доступу до мережі Інтернет, появи хмарних технологій i, що найголовніше, переходу користувачів від стаціонарних комп'ютерів до мобільних пристрої (Carson, 2017).

Із плином часу соціальними мережами стали називати ті мережі, які дають змогу їхнім користувачам вста- новлювати зв'язки між собою, обмінюватись інформацією та соціальним досвідом, використовуючи ресурси глобальної мережі Інтернет (Illyashenko, 2011). Такими мережами почали називати різні платформи, онлайнсервіси чи веб-сайти, призначені для побудови та організації соціальних взаємовідносин. За більш вузьким технологічним визначенням соціальна мережа - це інтерактивний веб-сайт 3 великою кількістю користувачів, контент якого наповнюють самі його учасники. Позаяк соціальна мережа $є$ автоматизованим соціальним середовищем, яке дає змогу його безпосереднім користувачам, об'єднаних спільним інтересом, активно спілкуватися між собою (Social network, 2019).

На сьогодні соціальна мережа Instagram є однією 3 найбільш популярних платформ для розвитку та просування бізнесу. Запущена ще у 2010 році, вона швидко завоювала популярність як серед фізичних, так і юридичних осіб. Темпи зростання мережі Instagram за 2018-2019 роки стали найбільшими серед більшості усіх подібних мереж (Active Instagram users, 2019), тобто кількість іiі користувачів збільшувалася щороку на декілька сотень мільйонів (+5\% кожного кварталу).

Аналіз актуальних досліджень і публікацій. Тер-

\section{Інформація про авторів:}

Грицюк Юрій Іванович, д-р техн. наук, професор, кафедра програмного забезпечення.

Email: yurii.i.hrytsiuk@lpnu.ua; https://orcid.org/0000-0001-8183-3466

Білецький Тарас Петрович, студент, кафедра програмного забезпечення. Email: tbiletskyi@gmail.com

Цитування за ДСТУ: Грицюк Ю. І., Білецький Т. П. Веб-додаток для маркетингового аналізу соціальної мережі Instagram. Науковий вісник НлтУ України. 2019, т. 29, № 6. С. 106-118.

Citation APA: Hrytsiuk, Yu. I., \& Biletskyi, T. P. (2019). Web Application for Marketing Analysis of the Social Network Instagram. Scientific Bulletin of UNFU, 29(6), 106-118. https://doi.org/10.15421/40290622 
мін "соціальні мережі" був введений до наукового обігу в 1954 році соціологом Джеймсом Барнсом у роботі "Класи та збори в норвезькому острівному приході", яка увійшла до збірки "Людські стосунки" (Barnes, 1954). Він охарактеризував коло друзів певної людини як мережу, яка існує у вигляді системи точок, з'єднаних між собою. "Точками" такої системи є люди, а лінії, які їх з'єднують, вказують, як саме вони взаємодіють між собою (Zabastanskaya \& Abramchuk, 2017). Проблеми розвитку соціальних мереж, їхніх властивостей, структурної побудови, діяльності мережевого суспільства, його віртуалізацію та інше вивчає значна кількість дослідників. Ці питання активно аналізують такі науковці, як А. Фомін, Д. Іванов, І. Семенова, В. Сілаєва, Г. Градосєльська, С. Коноплицький, В. Щербина, С. Прохоренко, С. Романенко, Н. Коритнікова та ін. Серед західних науковців заслуговують уваги праці М. Кастельса, П. Бурд'є, В. Бюля, Ж. Делеза, А. Турена, А. Раньї, П. Ердос та ін.

Не секрет, що соціальні Інтернет-мережі від часів свого створення набули значних якісних змін (Ageenko, 2019). Спочатку вони здійснювали функції базової взаємодії, а сьогодні ці мережі виконують різноманітні завдання для вирішення проблем, пов'язаних із відновленням чи налагодженням соціальних контактів, швидким обміном інформацією тощо. Проблематику таких соціальних мереж детально висвітлено в публікації Д Уоттса "Малі світи, динаміка мереж від порядку до випадковості", а в роботі М. Баханана "Nexus: малий світ і зачаровуюча світ наука про мережі". А. Барабазі у своїй монографії "Взаємопов'язаність, нова наука про мережу" довів складну внутрішню структуру соціальних мереж і показав, що вони не $є$ хаотичним утворенням (Ваrabasi, 2002).

Проблема дослідження соціальних мереж стала предметом зацікавленості таких західних вчених, як Д. Белл, А. Тоффлера, Дж. Гэлбрейта, Р. Інгельгарта та ін. Такі вітчизняні вчені як Є. Акімова, Ю. Д. Бабаєва, О. П. Белінська, А. Є. Войскунський, А. Є. Жичкина, Д. В. Іванов, Д. І. Кутюгін, В. А. Солодосник і О. Г. Філатова у своїх дослідженнях розглядають проблеми інтернет-комунікацій, спілкування та взаємозв'язок користувачів у мережі, їхній вплив на особистість та обізнаність ії користувачів. Вивченням інформаційного (мережевого) розвитку суспільства займаються Р. Ф. Абдєєв, С. Афанасьєв, В. Біанкі, С. Дука, В. Іноземцев, С. Дятлов, Н. Моісєєв, І. Мелюхін, А. Ракітов, А. Чугунов, А. Уткін і Р. Мюнх.

Згідно з їхніми дослідженнями, основною відмінністю соціальної мережі Instagram від інших $є$ використання відео- та фото-файлів як ефективних засобів комунікації між їі користувачами. В ній текстові дописи мають другорядне значення і тільки доповнюють медіаконтент (Grishchenko \& Nsesheva, 2013; Stelzner, 2012). Такий підхід є зручним для користувачів і вигідним для бізнес-акаунтів, позаяк візуальна інформація опрацьовується людиною значно швидше і найдовше затримується у пам'яті, ніж текстова чи звукова (Sitnik, 2014). Тому, якщо для звичайного користувача соціальна мережа є веб-сервісом, який можна використати для комунікації та обміну інформацією, то для бізнесу - це можливість популяризувати свій бренд, знайти клієнтів за обмеженого обсягу веб-ресурсів. Причина не тільки у величезній аудиторії користувачів і зручному інструментарію рекламування своїх товарів чи надання пос- луг, використовуючи медіа-дописи. Мережа Instagram пропонує багато таких можливостей, які значно полегшують ведення бізнесу на іiі просторах (Chloe West, 2019; Gunelius, 2010; Marketing, 2019; Zabastanskaya \& Abramchuk, 2017). Наприклад, наявність бізнес-акаунта дає можливість здійснювати налаштування та запуску різноманітної платної реклами, додати посилання на різні он-лайн магазини, виконати взаємодію із споживачами, стежити за конкурентами, і т.д.

Однак, з виникненням перспективних можливостей появляються й потенційні конкуренти, а користувачі соціальної мережі Instagram як постійні клієнти стають більш вимогливими до пропонованого контенту та менш піддатливими до звичайної реклами. Тому для успішного розвитку бізнесу через соціальну мережу в багатьох дослідників (Illyashenko, 2011) ще в 2009 році виникла ідея використання маркетингу - комплексу заходів щодо запровадження соціальних медіа-ресурсів для просування бізнес-акаунту (Carson, 2017; Stelzner, 2012). Хоча на сьогодні існує велика кількість маркетингових стратегій та методів аналізу різних соціальних мереж, однак вибір кожного із них здійснюється на підставі загальної статистики та відповідних метрик. Під Instagram-метриками розуміють показники, обчислені на підставі даних, зібраних із мережі, які використовують для отримання інформації про поточний стан акаунта та підготовку стратегії дій для подальшого його просування. Метрики обчислюють для налаштування бізнес-акаунта, який потрібно постійно популяризувати, використовуючи маркетингові підходи (Bora, 2018; Jackson, 2017; Kindness, 2018).

Через значну кількість акаунтів і потенційних користувачів, чималий обсяг інформації та, що найважливіше, часові обмеження виконання зазначених вище дій навіть досвідченим маркетологом не завжди вдається їх виконати вручну, належно і своєчасно. Розроблення сучасного ПЗ у вигляді веб-додатку для маркетингового аналізу соціальної мережі Instagram у реальному часі видається нам актуальним дослідженням, результати якого будуть корисними не тільки для бізнес-аналітиків, але й потенційних іiї користувачів - фізичних і юридичних осіб.

Об'єкт дослідження - маркетинговий аналіз соціальної мережі Instagram.

Предмет дослідження - методи та засоби маркетингового аналізу соціальної мережі, які дадуть змогу збирати різні дані, обчислювати на підставі них відповідні метрики і статистики, а також здійснювати автоматизацію таких дій користувача, як вподобання, коментування та стеження.

Мета дослідження полягає у розробленні веб-додатку для маркетингового аналізу соціальної мережі Instagram, що дасть змогу в реальному часі отримувати достовірну інформацію про поточний стан бузнес-акаунта та уможливить формування стратегії для подальшого його просування.

Для реалізації зазначеної мети потрібно вирішити такі основні завдання:

1) встановити потребу маркетингового аналізу соціальної мережі Instagram, на підставі чого розробити комплекс заходів для просування бізнес-акаунта шляхом запровадження відповідних медіа-ресурсів;

2) з'ясувати причини застосування Instagram-метрик, статистик і автоматизації дій користувача для аналізу мар- 
кетингової інформації, на підставі яких визначити параметри поточного стану бізнес-акаунту і розробити стратегії для подальшого його просування;

3) спроектувати архітектуру веб-додатку для реалізації метрик, статистик і автоматизацій дій користувача, що дасть змогу розробити відповідний програмний засіб для маркетингового аналізу соціальної мережі Instagram в реальному часі;

4) розробити структуру організації баз даних для реалізації веб-додатку, оброблені дані яких є необхідними для авторизації та автоматизації дій користувача, а також обчислення відповідних метрик і статистик;

5) реалізувати веб-додаток $з$ використанням відповідної технології та мови програмування у певному середовищі розробки, а також системи управління базами даних;

6) зробити відповідні висновки та надати рекомендації щодо ефективного використання розробленого веб-додатку для маркетингового аналізу соціальної мережі Instagram.

1. Потреба маркетингового аналізу соціальної меpeжi Instagram. Загалом, робота соціальної мережі базується на обміні медіа-файлами між іiі користувачами. Кожен користувач мережі володіє акаунтом, на якому він може зберігати фото- чи відео-файли, завантажені зі свого пристрою чи безпосередньо створені вбудованими інструментами іiі інтерфейсу. Також користувачі мережі мають змогу переглядати та реагувати на дописи, викладені іншими користувачами. Допис, окрім медіафайлу, може додатково містити посилання на інших користувачів мережі та текстовий опис із ключовими словами (хештегами), які є своєрідними атрибутами, за якими можна групувати та шукати інші дописи.

У мережі Instagram основними способами реагування на допис іншого користувача є (Barabasi, 2002; comScore, 2019):

- вподобання - функція, яку використовують для вираження ставлення користувачів до того чи іншого контенту;

- коментування - функція, яка дає можливість користувачу висловити ставлення до розміщеного контенту;

- поширення - функція, яка виконує копіювання допису на свою сторінку зі збереженням посилання на його першоджерело.

Окрім акаунту, іншим важливим елементом інтерфейсу мережі Instagram для роботи з нею є рядок новин, на якому відображають дописи, опубліковані іншими іiі користувачами. Тут відображають новини тільки від тих користувачів, за якими стежить поточний користувач. Відповідно, можливість відстежувати інші акаунти означає наявність фоловерів, тобто тих акаунтів, які стежать за поточним користувачем. Іншими функціями мережі Instagram $€$ пошук акаунтів за їхнім іменем і пошук дописів за хештегами у текстовому описі до них. Однак, на практиці пошук акаунтів частіше відбувається шляхом їх перегляду, з якими є спільні підписники, є друзями в інших соціальних мережах чи які відстежують поточний акаунт.

Якщо порівнювати мережу Instagram 3 такими соціальними мережами, як Facebook чи Twitter, то Instagram - одна із найпростіших і зручних у використанні (Gunelius, 2010). Зумовлено це, передусім, орієнтацією на медіа-файли - як основний метод комунікації між користувачами, оскільки вони мінімально навантажують їх потрібною інформацією i, водночас, зберігають іiі інформативність. За статистикою (Illyashenko, 2011), потенційні користувачі соціальних мереж бажають все менше і менше часу витрачати на читання дописів, що дає медіа-новинам беззаперечну перевагу, адже їх легше і швидше опрацьовувати.

Статистика соціальної мережі Instagram свідчить про такі іï успіхи (Active Instagram users, 2019; Chloe West, 2019):

- 3 2012-го до 2018 року кількість активних користувачів зросла з 50 млн до одного мільярда;

- 64\% користувачів мережі є віком від 18 до 29 років;

- 80\% користувачів мережі відстежують бізнес-акаунти;

- 72\% користувачів хоча б один раз здійснювали покупку товару, про який дізналися в даній соціальній мережі;

• найбільш популярний допис - фото курячого яйця - 53 млн вподобань;

- більше 100 млн фото-файлів завантажують в соціальну мережу кожного дня;

- українська аудиторія соціальної мережі налічує 7,3 млн користувачів.

Різке зростання популярності соціальної мережі Instagram серед іiі користувачів неабияк зацікавило маркетологів і власників різних брендів. У 2018 році мережа Instagram налічувала 25 млн бізнес-акаунтів (Todd Clarke, 2019). Можливість зацікавити та залучити велику кількість нових клієнтів, не вкладаючи істотних ресурсів, збільшує конкуренцію серед тих, хто бажає це зробити завчасно, сьогодні чи зараз. Відповідно, ті, хто бажають отримати хороший результат, вдаються до маркетингового аналізу соціальної мережі Instagram.

В просторах мережі Інтернет доступна велика кількість порад, методів і стратегій просування бізнес-акаунтів (Bashinskaya, 2012; Scissons, Vo \& Sim, 2014). Beлика частина 3 них залежить від типу діяльності, яку здійснює власник бізнес-акаунта, аудиторії читачів, часу, їх місця знаходження, рівня зацікавленості опублікованими дописами і т.д. Зазвичай, це має істотний вплив на подальші прийняті рішення маркетологами щодо розвитку бізнесу в соціальній мережі. Тому їм важливо володіти даними, які, передусім, відображають поточний стан бізнес-акаунта, водночас вони можуть формувати подальшу стратегію дій щодо вирішення бізнес-завдань, а також забезпечуватимуть нагальне виконання цих дій.

Коли йдеться про дані та показники, цікаві для маркетолога в соціальній мережі Instagram, представляють інтерес метрики (Todd Clarke, 2019), які частково або повністю неочевидні як на перший погляд, однак потребують даних із мережі та виконання певних обчислень, щоб їх отримати. Прикладом таких Instagram-метрик можуть бути (Bora, 2018; Jackson, 2017; Kindness, 2018):

- популярність зроблених дописів;

- популярні хештеги (ключові слова);

- приріст користувачів, які стежать за певним бізнес-акаунтом;

- визначення найкращого часу для створення допису.

Для обчислення та подання подібних метрик використовують різного роду інструменти - програмні вебдодатки. Такі інструменти можуть додатково надавати можливість здійснювати автоматизацію певних процесів. Наприклад, створювати дописи та планувати їхню автоматичну публікацію у вказаний час чи виконувати пошук користувачів за певними параметрами (Schivinski \& Dąbrowski, 2013). Переваги та недоліки деяких веб-додатків показано в табл. 1 (Scissons, Vo \& Sim, 2014). 
Табл. 1. Веб-додатки для маркетингового аналізу соціальної мережі Instagram

\begin{tabular}{|c|c|c|}
\hline & Переваги & Недоліки \\
\hline Sprout Social & $\begin{array}{l}\text { - інтеграція з іншими соціальними мережами; } \\
\text { - аналіз акаунта на підставі метрик; } \\
\text { - аналіз конкурентів; } \\
\text { - автоматична публікація дописів. }\end{array}$ & $\begin{array}{l}\text { - перевантаження інтерфейсу функціями, призначеними } \\
\text { для інших соціальних мереж; } \\
\text { - аналітика доступна тільки для бізнес-акаунтів; } \\
\text { - відносно висока вартість використання: мін. } 100 \text { \$ммісяць. }\end{array}$ \\
\hline Buffer & $\begin{array}{l}\text { - інтеграція з різними соціальними мережами; } \\
\text { - автоматична публікація дописів одразу на декіль- } \\
\text { ка прив'язаних акаунтів; } \\
\text { - простий та зручний інтерфейс. }\end{array}$ & $\begin{array}{l}\text { - відносно висока вартість - } 99 \$ \text { мміс., що порівняно з інши- } \\
\text { ми - найдешевший тарифний план; } \\
\text { - обмежена аналітика на підставі тільки даних про кількість } \\
\text { дописів, вподобань та коментарів; }\end{array}$ \\
\hline Combin & $\begin{array}{l}\text { - аналіз акаунта на підставі метрик; } \\
\text { - можливість здійснювати пошук допису чи корис- } \\
\text { тувача на підставі заданих характеристик: стать, } \\
\text { мова, популярність, хештеги, т. п. }\end{array}$ & $\begin{array}{l}\text { - програма } є \text { настільною, тобто перед запуском ії потрібно } \\
\text { завантажити та встановити; } \\
\text { - аналітика доступна тільки у платній версії - 30\$/місяць. }\end{array}$ \\
\hline
\end{tabular}

Отже, для успішного розвитку бізнесу через соціальну мережу Instagram варто використовувати маркетинговий аналіз іiї бізнес-акаунтів, що дасть змогу маркетологам розробити комплекс заходів для його просування шляхом запровадження відповідних медіа-ресурсів.

2. Застосування Instagram-метрик для аналізу маркетингової інформації. Під Instagram-метриками розуміють зібрані та опрацьовані дані із соціальної мережі, які використовують для отримання інформації про поточний стан бізнес-акаунта та формування стратегії для подальшого його просування. Дослідивши та проаналізувавши ряд ресурсів (Bora, 2018; Illyashenko, 2011; Kindness, 2018; Todd Clarke, 2019), було виділено такі Instagram-метрики, як інтенсивність залучення підписників, графік їхньої активності та місце перебування, зворотне стеження підписників, а також популярні хештеги. Проаналізуємо кожну $з$ цих метрик дещо детальніше.

Інтенсивність залучення (англ. Engagement Rate) це частка аудиторії (підписників) певного користувача, яка взаємодіє із його дописами. Цю метрику можна обчислити як загальну для всіх дописів, або для кожного допису окремо. Під взаємодією із дописами розуміють такі дії над ними, як вподобання, коментування та поширення. Ця метрика дає змогу визначити, на скільки аудиторія користувачів зацікавлена дописами, які публікуються в бізнес-акаунті; яка тематика є більш/менш цікава для цієї аудиторії. Метрику для $j$-го допису можна обчислювати за такою формулою:

$$
I 3 Д_{j}=\frac{K B_{j}+K K_{j}+K \Pi_{j}}{K \Pi_{j}} \cdot 100, j=\overline{1, n}, \%,
$$

де: $I 3 Д_{j}-$ інтенсивність залучення $j$-го допису; $K B_{j}-$ кількість вподобань користувачами $j$-го допису; $K Д_{j}-$ кількість коментарів користувачами $j$-го допису; $K \Pi_{j}-$ кількість поширень користувачами $j$-го допису; $n-$ кількість залучених дописів.

Усереднену інтенсивність залучення дописів визначають як середнє арифметичне серед інтенсивностей залучення усіх дописів, а саме

$$
3 I 3=\frac{100}{n} \sum_{j=1}^{n} I 3 Д_{j}, \%,
$$

де: ЗІ3 - усереднена інтенсивність залучення дописів.

Популярні хештеги (англ. Popular Hashtags) - це метрика, яка у табличному вигляді відображає перелік тих хештегів, які $є$ найбільш популярними серед користувачів. Хештег - це ключове слово, яке починається зі знаку "\#" і яке використовують в текстових описах дописів для тематичного об'єднання його з іншими дописами, які мають ідентичні хештеги. Отже, у межах мережі Instagram за хештегом можна знайти всі дописи, які їх містять.
Для виявлення популярних хештегів потрібно:

1) обчислити для усіх дописів користувача інтенсивність ї залучення;

2) посортувати дописи у порядку спадання інтенсивності їх залучення;

3) з кожного допису отримати використані хештеги та подати їх у таблиці в порядку відповідно до посортованих дописів, з яких їх отримали.

Графік активності підписників (англ. Followers Activity Timeline) - це метрика, яка у вигляді бульбашкової діаграми (вісь абсцис - години від 00:00 до 23:59, вісь ординат - дні тижня від Пн до Нд) зображує день та час активності підписників певного бізнес-акаунта мережі Instagram. Ця метрика $є$ корисною, наприклад, для виконання публікації дописів у ті проміжки часу, коли підписники є найбільш активними.

Для створення графіку активності підписників потрібно виконати такі кроки:

1) отримати дописи одного підписника;

2) проаналізувати час створення усіх цих дописів;

3) вибрати день і час пікової активності цього підписника;

4) виконати кроки 1-3 для усіх підписників користувача.

Micце перебування підписників (англ. Followers Location) - це метрика, яка у вигляді карти світу та відповідної таблиці відображає інформацію про те, де та скільки в кожній 3 країн проживає підписників. Користь цієї метрики в тому, щоб розуміти, з яких країн користувачі переглядають створені дописи. Це допомагає маркетологам підбирати правильний контент для дописів (наприклад, дублювати іншою мовою).

Для подання місця перебування підписників потрібно виконати такі кроки:

1) отримати дописи одного підписника;

2) проаналізувати місце створення (широту і довготу) цих дописів;

3) визначити назву країни за отриманими координатами;

4) постановити, що підписник перебуває у країні, яка найчастіше була згадана у дописах;

5) виконати кроки 1-4 для усіх підписників.

Оскільки користувачі можуть публікувати дописи та прикріпляти до них будь-яке місце розташування (наприклад, якщо вони подорожують), то визначена метрика не є достовірною на $100 \%$.

Зворотне відстеження підписників (англ. Reverse Tracking of Followers) - це метрика, яка у вигляді діаграми та таблиці для кожного підписника певного бізнес-акаунта показує, на яку частку своїх підписників він є теж підписаний. Вона дає змогу визначити, скільки серед підписників $є$ таких, що зазвичай підписуються на тих, хто підписався на них. Цю інформацію в подальшому можна використати для автоматизованого стеження (підписування) за акаунтами з високим/низь- 
ким показником зворотного стеження для того, щоб вони підписувалися на поточний акаунт.

Для визначення такої метрики потрібно виконати такі кроки:

1) для кожного підписника проаналізувати його підписників;

2) для кожного підписника проаналізувати тих, на кого він підписаний;

3) знайти збіги у двох проаналізованих переліках;

4) кількість збігів поділити на кількість підписників підписника, визначається у \%;

5) виконати кроки 1-4 для усіх підписників певного бізнес-акаунта.

Отже, для отримання достовірної інформації про поточний стан бізнес-акаунта та розроблення стратегії для подальшого його просування варто використовувати відповідні метрики, обчислені на підставі даних, зібраних і опрацьованих із соціальної мережі Instagram.

3. Застосування Instagram-статистик для аналізу маркетингової інформації. Instagram-статистика $є$ підставою для побудови Instagram-метрик. Зібрані та опрацьовані дані із соціальної мережі Instagram використовують для отримання інформації про поточний стан бізнес-акаунта (Todd Clarke, 2019). Відмінність статистик від метрик полягає у тому, що для їх отримання не потрібно застосовувати спеціальних математичних алгоритмів, а опрацювати та подати дані із соціальної мережі у зручному для опрацювання вигляді з можливістю пошуку та сортування. Дослідивши та проаналізувавши ряд ресурсів (Bora, 2018; Kindness, 2018; Stelzner, 2012), було виділено такі Instagram-статистики, як загальна інформація про користувача, його підписників, дописи та тих, хто їх вподобав. Проаналізуємо кожну з цих статистик дещо детальніше.

Загальна інформація про користувача (англ. Basic User's Info) - подання про певного користувача такої інформації, як: кількість підписників, кількість дописів, кількість тих бізнес-акаунтів, за якими стежить користувач, його фото та ім'я.

Інформація про дописи користувача (англ. User's Media Information) - подання у табличному вигляді такої інформації, як: фото та текст дописів, час публікації, кількість вподобань, коментарів і переглядів, хештеги дописів.

Інформація про підписників користувача (англ. User's Following Information) - подання у табличному вигляді такої інформації, як: фото, ім'я, кількість підписників, дописів, і тих, за ким він стежить.

Інформація про тих, хто вподобав дописи користувача (англ. User's likers Information) - подання у табличному вигляді такої інформації, як: фото та ім'я, кількість підписників, дописів, і тих, за ким він стежить; чи $\epsilon$ він або підписником, або сам підписаний на певного користувача, скільки вподобань він залишив і які саме дописи вподобав. Також для цієї статистики обчислюють загальну кількість вподобань усіх дописів користувача, загальну кількість тих, хто вподобав допис хоча б один раз, частку підписників серед них. Для кожної таблиці можна виконувати сортування за усіма текстовими та числовими стовпцями і здійснити пошук за будь-якою ознакою потрібну інформацію.

Отже, для отримання достовірної інформації про поточний стан бізнес-акаунта та розроблення стратегії для подальшого його просування варто використовувати відповідні статистики, обчислені на підставі даних, зібраних і опрацьованих із соціальної мережі Instagram.

4. Застосування автоматизації дій користувача для аналізу маркетингової інформації у реальному часі. Під автоматизацією дій користувача розуміють налаштування та запуск алгоритму автоматичного виконання деякого переліку дій від імені бізнес-акаунта для того, щоб інші його користувачі звернули на це увагу та підписалися на нього у відповідь. Дослідивши та проаналізувавши ряд ресурсів (Bora, 2018; Kindness, 2018; Stelzner, 2012), було виділено такі автоматизації дій користувача, як вподобати допис чи прокоментувати його, розпочати/припинити стежити за користувачем (підписатись/відписатись), а також прокоментувати допис. Проаналізуємо кожну 3 цих автоматизацій дещо детальніше.

Вподобати допис (англ. Prepare a Post) полягає в тому, щоб налаштувати параметри веб-додатку на періодичне виконання вподобання чужих дописів, яке зводиться до пошуку користувачів, яким потрібно вподобати дописи, та до пошуку безпосередньо дописів, які потрібно вподобати. Ці параметри не є обов'язковими, позаяк вимагають вказати тільки частоту та часові рамки виконання автоматизації дій користувача.

Для налаштування пошуку користувача потрібно вказувати такі параметри, як: кількість підписників; кількість акаунтів, за якими він стежить; кількість дописів; значення метрики Engagement Rate; наявність спільних підписників 3 акаунтом, від імені якого виконується автоматизація дій; хоча б один раз вподобав допис акаунта, від імені якого виконується автоматизація дій; хоча б один раз прокоментував допис акаунта, від імені якого виконується автоматизація дій.

Для налаштування пошуку допису можна вказувати такі параметри, як: кількість переглядів, вподобань та коментарів, використані хештеги. Важливо знати, що соціальна мережа Instagram накладає обмеження на кількість вподобань, які користувач може задати у розмірі 350 дій/год.

Розпочати стежити за користувачем - підписатися (англ. Begin Following the User - Subscribe) полягає в тому, щоб налаштувати параметри веб-додатку на періодичне виконання алгоритму підписання на нових користувачів мережі Instagram. Налаштування параметрів цього алгоритму зводиться до пошуку нових користувачів, на яких потрібно підписуватися, а також встановлення частоти та часових рамок виконання алгоритму.

Соціальна мережа Instagram накладає обмеження на кількість підписань, які користувач може здійснити, а саме - 20 дій/год і 200 дій/день.

Припинити стежити за користувачем - відписатися (англ. Stop Watching User - Unsubscribe) полягає в тому, щоб налаштувати параметри веб-додатку на періодичне виконання алгоритму на відписання від тих користувачів, за якими відбувається стеження. Причина в тому, що максимальна кількість акаунтів, за якими одночасно може стежити мережа, становить 7500 акаунтів. Налаштування параметрів цього алгоритму зводиться до вибору дій відписання від акаунта, який стежить або ні у відповідь, а також встановлення частоти та часових рамок виконання алгоритму.

Соціальна мережа Instagram накладає обмеження на кількість відписань від інших користувачів, а саме - мінімально 20 дій/год і максимум 200 дій/день. 
Прокоментувати допис (англ. Comment on the Post) полягає в тому, щоб налаштувати параметри веб-додатку на періодичне виконання алгоритму коментування дописів користувачів мережі Instagram. Налаштування параметрів цього алгоритму зводиться до пошуку нових користувачів, для яких потрібно прокоментувати дописи; до безпосереднього пошуку дописів, які потрібно вподобати; встановлення частоти та часових рамок виконання алгоритму, а також підбору типових текстових повідомлень, які алгоритм випадково вибиpaє із вказаного переліку та використовує як коментар.

Соціальна мережа Instagram накладає обмеження на кількість виконання користувачем коментувань дописів у розмірі 60 дій/год.

Отже, для маркетингового аналізу соціальної мережі Instagram в реальному часі варто застосувати автоматизацію дій користувача для того, щоб інші користувачі звернули на них увагу та підписалися на акаунт, від імені якого виконувалися автоматизації вказаних дій.
5. Проектування архітектури веб-додатку для реалізації метрик, статистик і автоматизацій дій користувача. Для реалізації етапу проектування архітектури веб-додатку використано інструмент Microsoft Visio 2013, а також такі технології (Butch, Rumbaugh \& Jacobson, 2000; Stelzner, 2012):

- мова моделювання UML для проектування діаграми прецедентів і діаграми класів;

• ER-модель для проектування концептуальної моделі бази даних.

Для побудови ER-діаграм було використано дві нотації:

- нотацію "Пітера Чена" - для проектування документоорієнтованої бази даних класу NoSQL під СУБД Couchbase;

- нотацію "Вороняча лапка" - для проектування реляційної бази даних під СУБД SQL Server.

Для ознайомлення із функціональними характеристиками веб-додатку розроблено відповідну діаграму прецедентів (рис. 1). Архітектура веб-додатку базується на використанні розподіленого архітектурного стилю Клієнт-сервер та шаблону проектування MVC (англ. Model-View-Controller) (рис. 2).

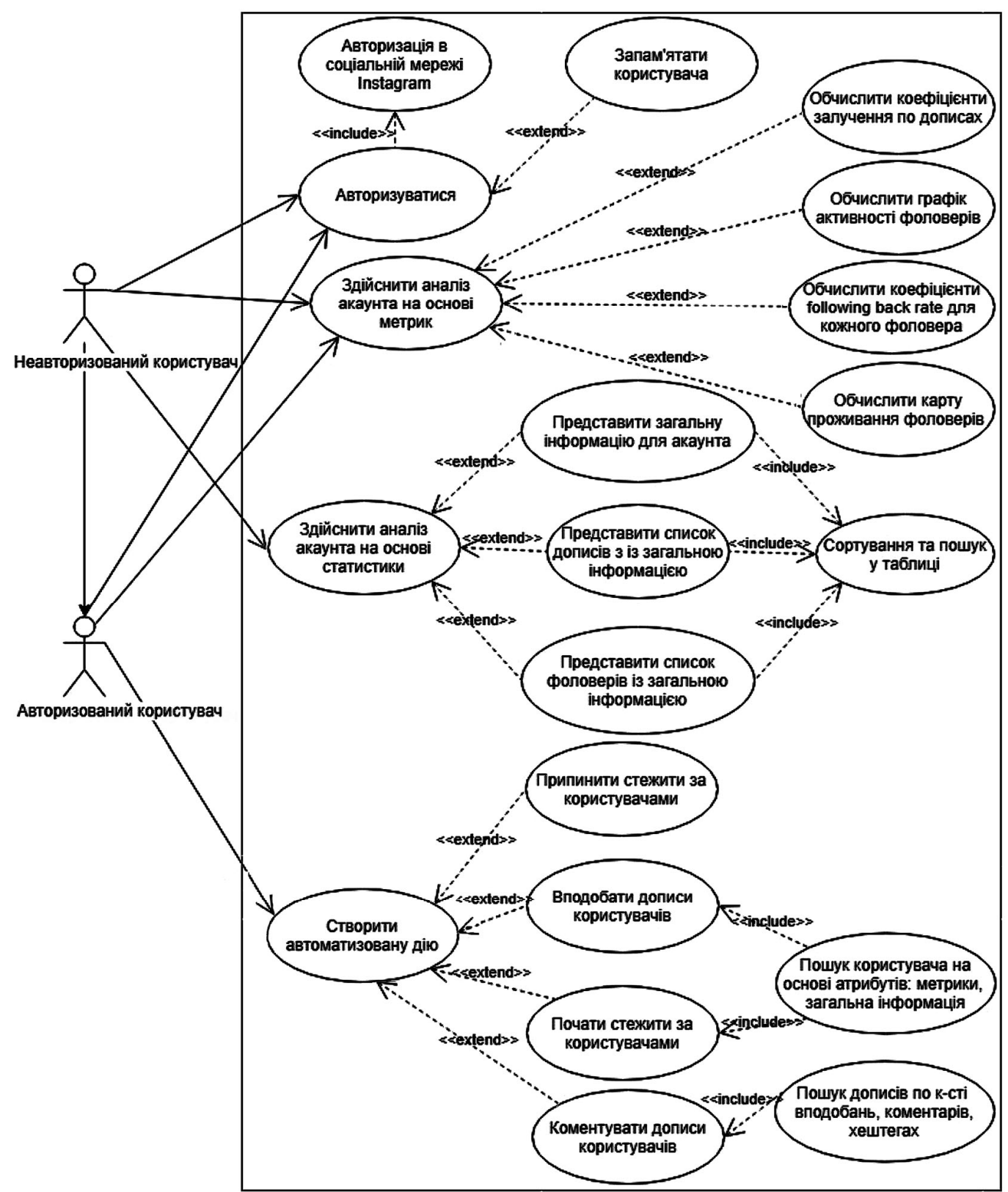

Рис. 1. Діаграма прецедентів для розроблюваного веб-додатку 


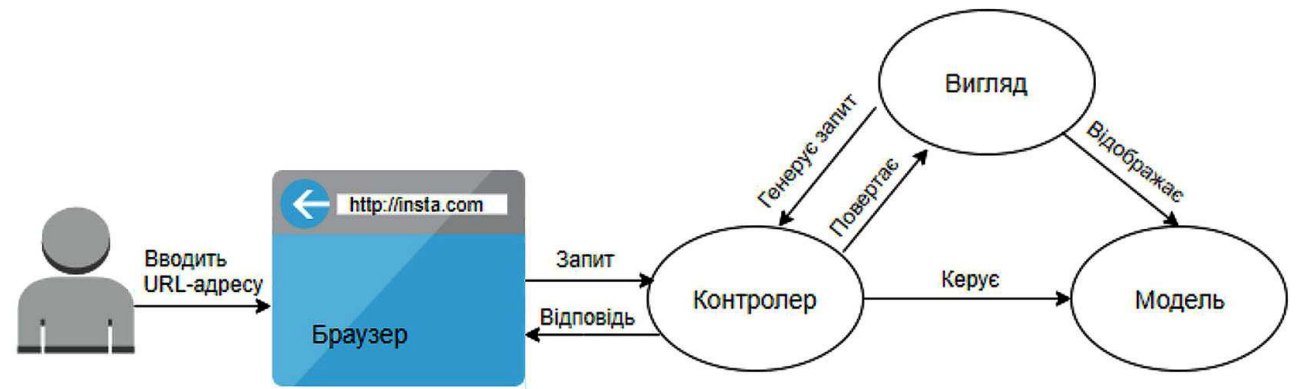

Рис. 2. Архітектура системи реалізації веб-додатку

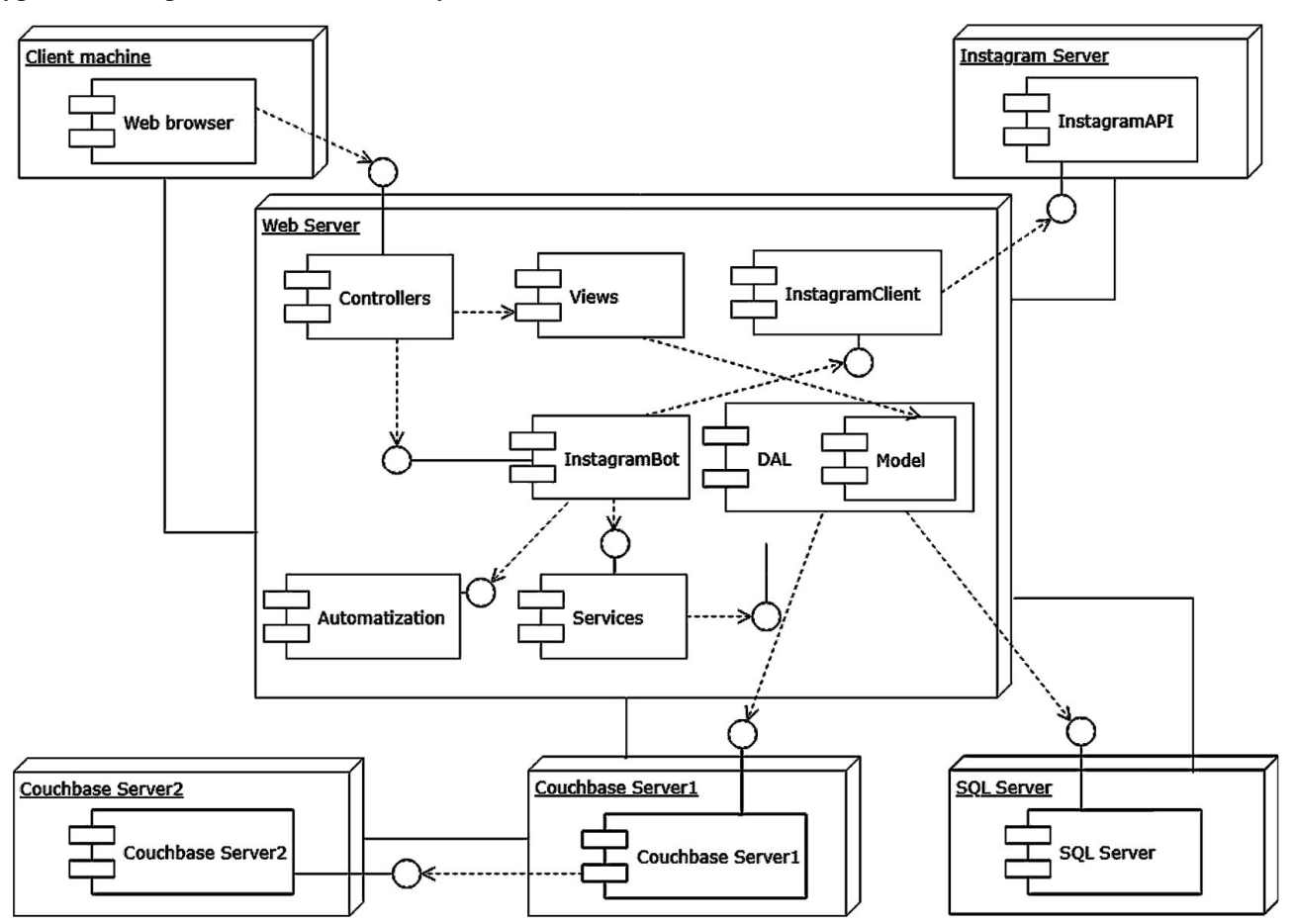

Рис. 3. Діаграма розгортання архітектури веб-додатку

Клієнт-серверна архітектура веб-програмування передбачає, що веб-додаток використовуватиме веб-сервер, який відповідатиме на запити, надіслані від клієнтів (браузерів), використовуючи для цього стандартні TCP/IP протоколи (рис. 3).

Шаблон проектування MVC поділяється на три компоненти:

- Model (Moдель) - відповідає за управління даними та відображає стан веб-додатку;

- View (Вигляд) - реалізує користувацькі інтерфейси для подання інформації, отриманої з Моделі;

Controller (Контролер) - обробляє запити користувачів, зазвичай, згенеровані під час взаємодії із Виглядом. Він генерує відповідь Вигляду з відповідної Моделі.

Запропоновану вище архітектуру веб-додатку реалізовано за допомогою фреймворка від компанії Microsoft ASP.NET MVC 5, який дає змогу розробляти як веб-додаткт, так і веб-сервіси (Conallen, 2001; Stelzner, 2012). Переваги цього фреймворка полягають у таких його можливостях, як:

• легка модифікація чи заміна його компоненти;

- реалізація зручного механізму для управління інфраструктурою маршрутизації запитів;

- використання серверної мови програмування С\# за допомогою компоненти View для генерування HTML-коду;

- відносно легка реалізація процедур авторизації дій користувача, ролей акторів і їхніх груп, здійснення кешування даних, сесії користувача та управління станом його акаунта;

- значна швидкість реалізації порівняно з іншими технологіями, які базуються на скриптах (РНР, тощо);
- застосування .NET, що дає змогу використовувати мови C\#, $\mathrm{VB}, \mathrm{C} / \mathrm{C}++$ та ін.

Фізично архітектура системи реалізації веб-додатку розміщена на таких фізичних вузлах:

- веб-сервер - отримує запити від клієнтських машин, обробляє їх, звертаючись до серверів баз даних і сервера соціальної мережі Instagram, а також повертає відповідь назад клієнтській машині;

- клієнтська машина - виконує запити до веб-сервера та відображає отриману відповідь;

- сервер бази даних SQL Server - зберігає дані про користувачів веб-додатку та створені ним автоматизації дій;

- сервер бази даних Couchbase Server - зберігає дані, необхідні для обчислення метрик і статистик;

- сервер соиіальної мережі Instagram - виконує запити для отримання даних з мережі Instagram чи здійснює виконання заданих дій користувача.

3 точки зору логічної архітектури, то веб-додаток складається з таких програмних компонент:

- Controllers - обробляє запити користувачів, використовуючи для цього такі компонети, як InstagramBot та Views;

- Views - реалізує користувацькі інтерфейси для подання інформації, отриманої у вигляді компоненти Model;

- Models - відповідає за управління даними та відображає стан веб-додатку. Models є підкомпонетою компоненти DAL;

- InstagramBot - реалізує базові функції веб-додатку, використовує компоненти Automatization, InstagramClient та Services;

- InstagramClient - забезпечує безпосередній доступ до Instagram-сервера;

- Automatization - відповідає за автоматизацію дій користувача; 
- Services - здійснює доступ до бази даних через проміжну компоненту DAL;

- DAL (англ. Data Access Library) - здійснює безпосередній доступ до відповідних баз даних SQL Server Database та Couchbase server;

- SQL Server Database - зберігає дані про користувачів вебдодатку та створені автоматизації дій користувача;

- Couchbase Database - зберігає дані, необхідні для обчислення метрик і статистик;

- Instagram Server - повертає дані, необхідні для обчислення метрик і статистик.

Для подання статичної складової фізичної архітек- му розгортання (див. рис. 3). Оскільки ця діаграма містить і логічні компоненти та зв'язки між ними, то вона також відображає і логічну архітектуру системи реалізації веб-додатку.

Динамічна складова архітектури системи реалізації веб-додатку подана за допомогою діаграми послідовностей (рис. 4), яка відображає впорядковану за часом взаємодію перерахованих вище програмних компонент під час аналізу бізнес-акаунта на підставі метрик. Аналогічно відбувається взаємодія компонент веб-додатку й при обчисленні відповідних метрик і статистик.

тури системи реалізації веб-додатку розроблено діагра-

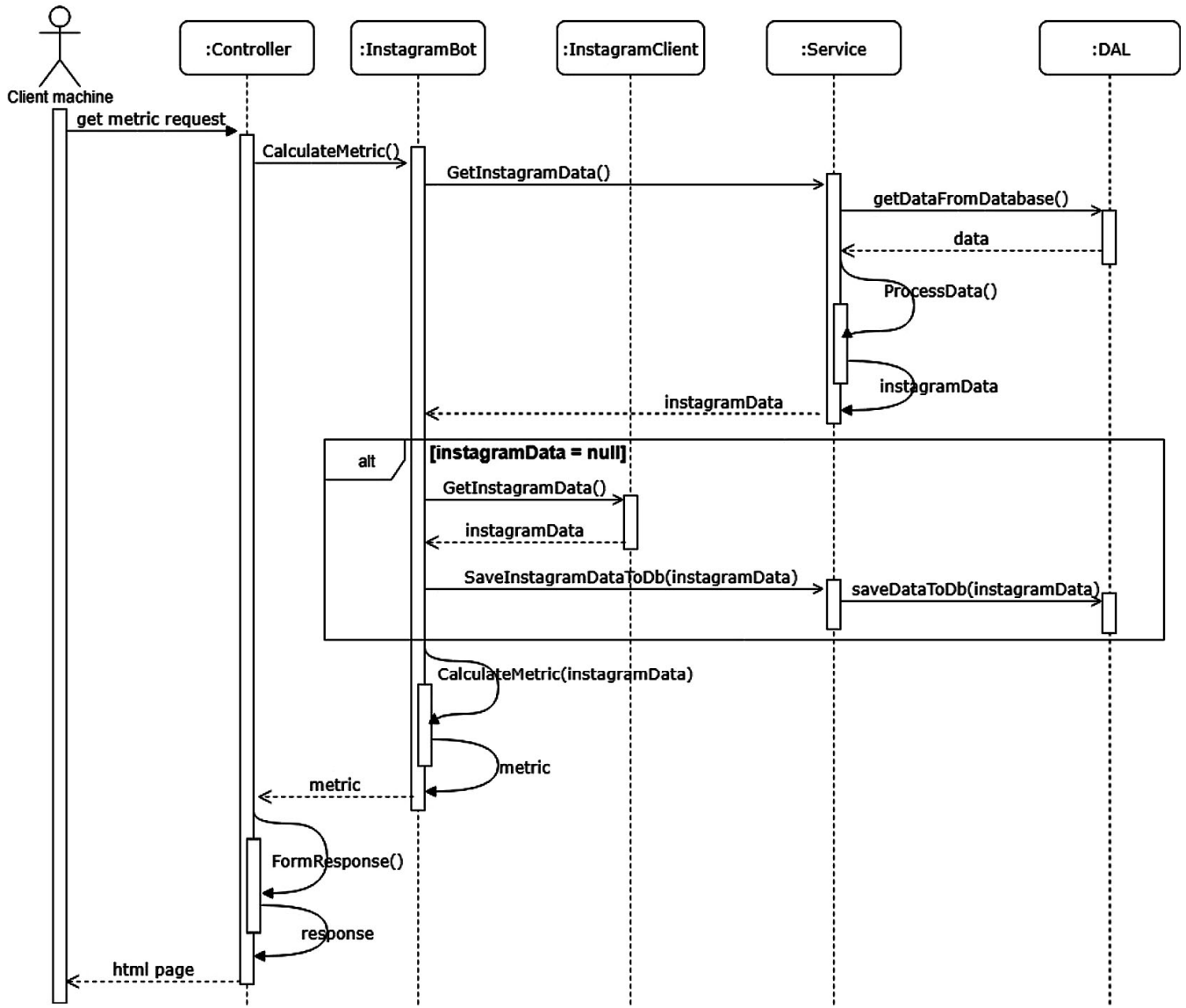

Рис. 4. Діаграма послідовностей виконання обчислень Instagram-метрик

Кожна із компонент має бути максимально незалежною від реалізації інших компонент, які вона використовує. Здійснюється це за допомогою шаблону проектування Bпровадження залежності (англ. Dependency Injection). Для веб-додатку суть шаблону полягає в тому, щоб замість створення та використання об'єкта одного класу (залежності) в межах другого класу, можна було передавати в конструктор другого класу необхідний інтерфейс, який реалізовує перший клас.

Отже, спроектовано архітектуру веб-додатку для реалізації запропонованих метрик, статистик і автоматизацій дій користувача, що дасть змогу розробити відповідний програмний засіб для маркетингового аналізу соціальної мережі Instagram в реальному часі, який уможливить отримання достовірної інформації про поточний стан бузнес-акаунта.

6. Проектування структур організації баз даних для веб-додатку. Для реалізації веб-додатку потрібно спроектувати дві бази даних, одна 3 яких буде реляційною - SQL Server, а інша - Couchbase Server типу NoSQL (Macyaszek, 2002; Software, 2019).
База даних SQL Server відповідає за зберігання даних, необхідних для аутентифікації та авторизації користувача, а також автоматизації його дій. На концептуальному рівні проектування ця база даних представлена не буде, оскільки ії розмір не перевищує 10-ти таблиць. На логічному рівні проектування базу даних було представлено у вигляді діаграми "сутність-зв'язок", використавши для цього нотацію "Вороняча лапка". На фізичному рівні проектування було відображено діаграму, створену засобами SQL Server Management Studio. Також описано запити до бази даних і методи їх оптимізації.

База даних під управлінням Couchbase Server призначена для зберігання даних, які отримано із соціальної мережі Instagram, а також для розрахунку метрик і відображення статистик. На концептуальному рівні проектування цю базу даних представлено у вигляді діаграми "сутність-зв'язок", використавши для цього нотацію "Пітера Чена". Оскільки база даних під управлінням Couchbase Server не є реляційною, то іiі схема формується динамічно залежно від структури документів, які вона зберігає. Кожному документу в базі даних від- 
повідає певний клас компонент DAL (англ. Data Access Library). Тому на логічному рівні проектування базу даних представлено у вигляді діаграми класів. Водночас, на фізичному рівні вона представлена у тому вигляді, в якому буде зберігатися на сервері - у вигляді json-документів. Також описано запити до бази даних і методи їх оптимізації.
Концептуальна модель бази даних Coиchbase Server передбачає схематичне відображення сутностей предметної області та зв'язків між ними без прив'язки до моделі даних (наприклад, реляційної) чи конкретної СУБД. Основна мета проектування цієї бази даних на концептуальному рівні полягає у визначенні переліку сутностей, які зберігатимуться у ній, їхніх атрибутів i зв'язків між ними.

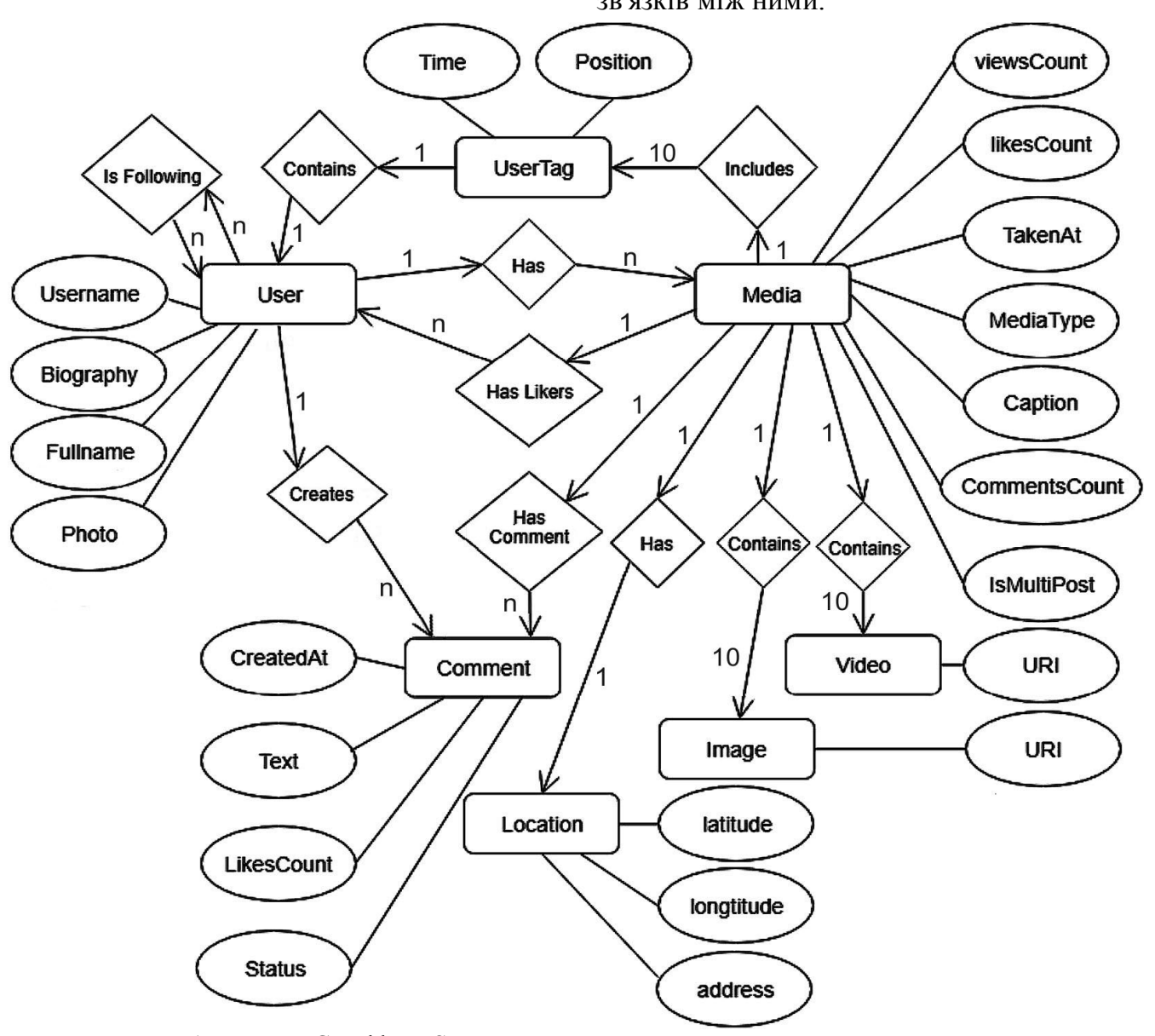

Рис. 5. Концептуальна модель бази даних Couchbase Server

Концептуальна модель бази даних Couchbase Server (рис. 5) відображає найважливіші сутності предметної області соціальної мережі Instagram, їхні основні атрибути та зв'язки (Butch, Rumbaugh \& Jacobson, 2000; Conallen, 2001). Бази даних Couchbase Server має такі сутності:

- користувач - відображає користувача соціальної мережі Instagram;

- медіa - допис, створений користувачем, може містити як відео-, так і фото-файли;

- коментар - відображає коментар, залишений користувачем під дописом;

- фото - є частиною сутності Медіа, містить такі параметри, як ширина, висота та посилання на фото-файл;

- відео - $є$ частиною сутності Медіа, містить такі параметри як ширина, висота та посилання на відео-файл;

- прикріплення користувача - посилання на користувача мережі Instagram, яке можна додавати до дописів;

- локація - відображає місцезнаходження користувача, який зробив допис.

Логічна модель бази даних Cоисhbase Server базується на підставі побудови її концептуальної моделі. Ця модель вже прив'язана до певної структури даних реляційних таблиць та колонок. Назви сутностей та атрибутів цієї моделі вже більше відповідають бізнес-моделі. Модель даних $є$ нормалізованою до потрібного рівня. Зв'язки між сутностями позначаються різними типами $(1: 1,1: \mathrm{N}, \mathrm{N}: \mathrm{N})$. На цьому рівні модель все ще не залежить від конкретної СУБД.

На рис. 6 зображена логічна модель бази даних Соuchbase Server у вигляді діаграми класів, які формують компоненту "Модель", а вона водночас є частиною шаблону проектування MVC.

Фізична модель бази даних SQL Server походить від іiї логічної моделі, містить всі артефакти, необхідні для створення відношень між таблицями чи досягнення продуктивності, використовуючи індекси різного типу. Тобто вона описує те, як дані представлено та зберігаються в ній, використовуючи для цього конкретну СУБД (Butch, Rumbaugh \& Jacobson, 2000; Macyaszek, 2002). На рис. 7 зображена фізична модель бази даних SQL Server у вигляді взаємопов'язаних реляційних таблиць та атрибутів, що відповідають конкретній СУБД SQL Server.

Отже, для реалізації веб-додатку спроектовано структури організації двох баз даних: SQ1 Server - для зберігання даних, необхідних для здійснення авторизації та автоматизації дій і Couchbase Server - для зберігання даних, необхідних для здійснення обчислення метрик і статистик. Розроблено відповідні компонентиклієнти для доступу до цих баз даних. 


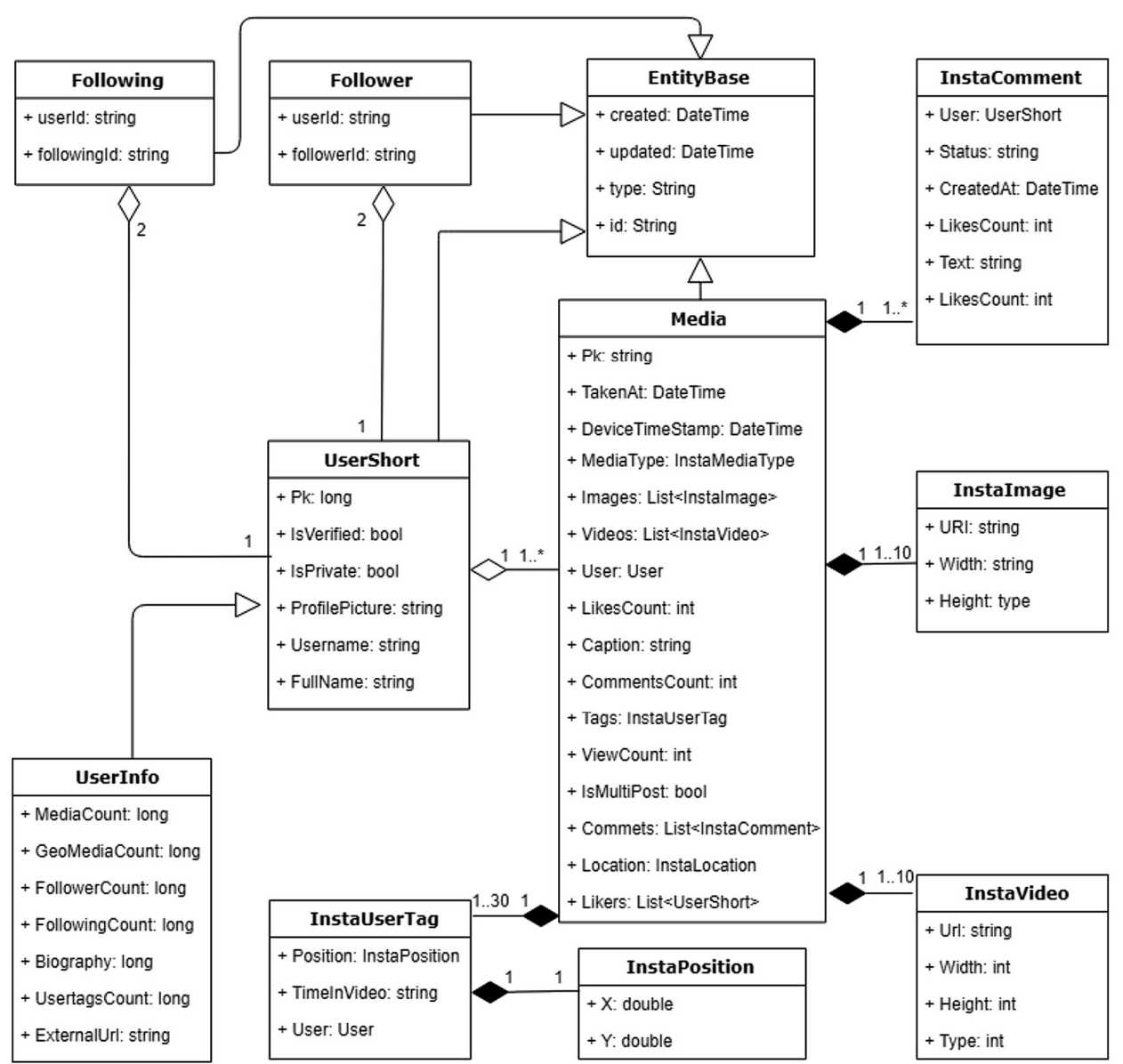

Рис. 6. Логічна модель бази даних Couchbase Server

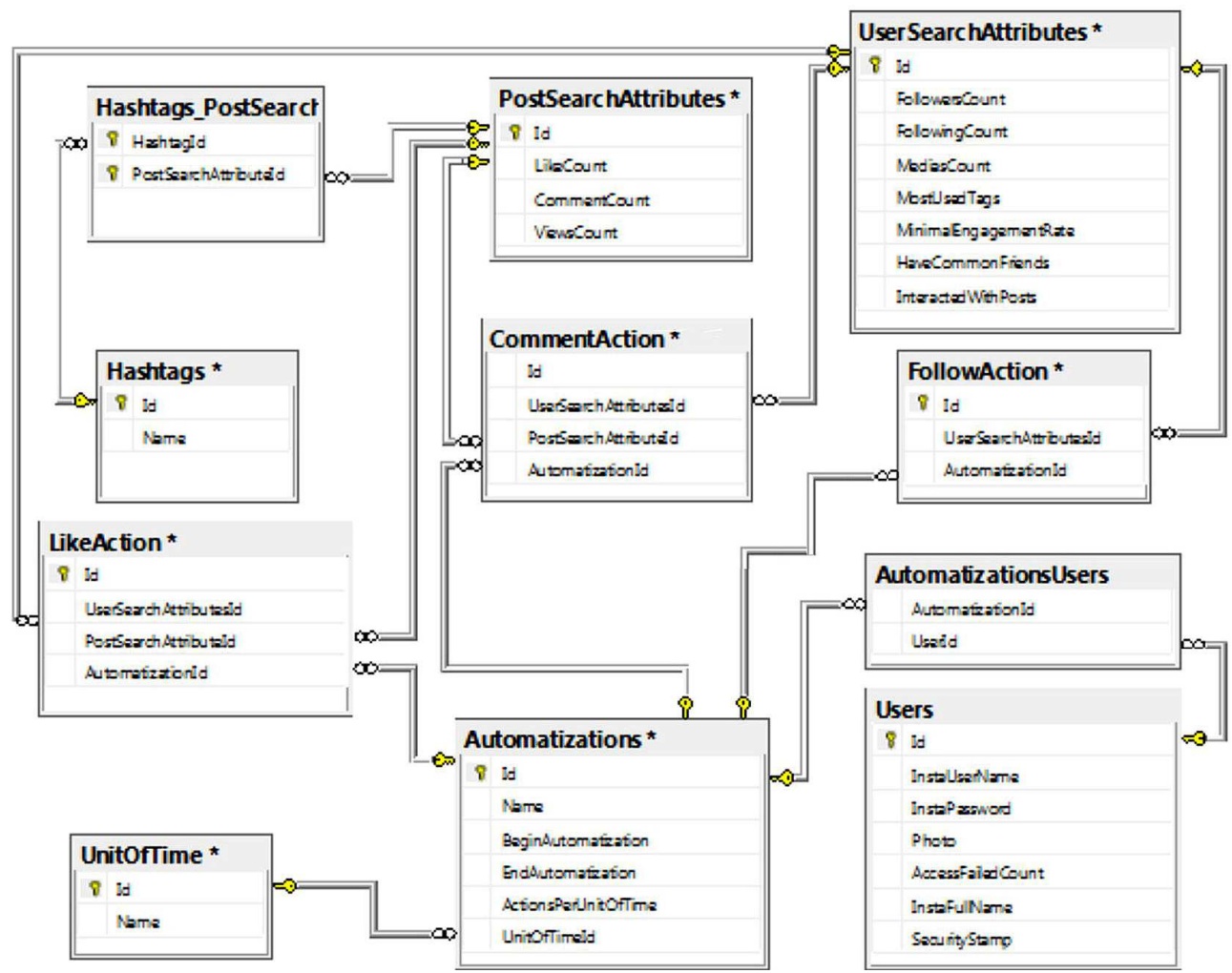

Рис. 7. Фізична модель бази даних SQL Server

7. Реалізація веб-додатку. Для розроблення веб-додатку використано систему інтегрованої розробки Visual Studio 2017. Відповідно до спроектованої архітектури веб-додатку (див. п. 5), його реалізовано у вигляді окремих компонент, кожна 3 яких відповідає за виконання певних функцій. Ці компоненти складаються 3 групи класів, концептуально або логічно пов'язаних між собою.

Для реалізації веб-додатку, окрім основного фреймворка ASP.NET MVC 5, було використано ряд зовнішніх бібліотек (Conallen, 2001; Software, 2019): 
- InstaSharper - реалізує клієнт для виконання запитів до Instagram сервера;

- Ninject - реалізує шаблон проектування "Впровадження залежностей" (англ. Dependency Injection), який використовують для послаблення залежностей між класами;

- Log4net - відповідає за впровадження системи ведення логування;

- CouchbaseNetClient - реалізує клієнт для роботи із базою даних Couchbase Server;

- Automapper - peалізує методи для копіювання даних між об'єктами різних класів;
- Two10.CoutryLookup - дає змогу отримати інформацію про місце на карті за вказаною довготою та широтою.

На стороні Frontend було розроблено веб-сторінку та інші елементи інтерфейсу користувача, призначені для роботи з основним функціями веб-додатку. Загальний інтерфейс додатку складається з динамічного елемента - сторінки та 3 трьох статичних елементів: меню, шапка та підвалу (рис. 8).

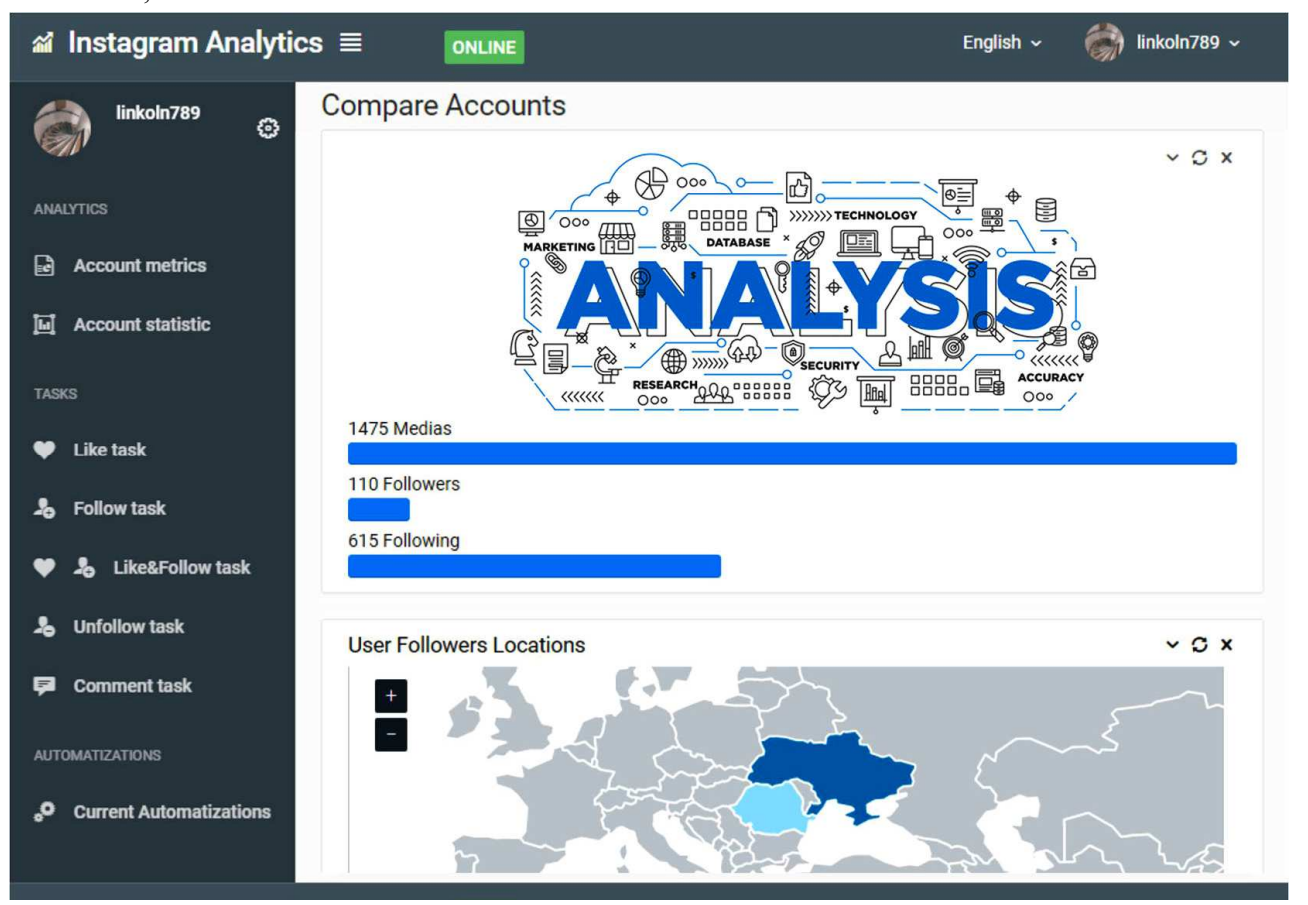

Рис. 8. Загальна структура інтерфейсу користувача веб-додатку

Для реалізації баз даних SQL Server використано утиліту SQL Server Management Studio. Оскільки ця база даних відповідає тільки за такі характеристики, як авторизація та виконання автоматизації дій користувача, то їі розміри незначні - декілька таблиць. Тому цю базу даних було спроектовано на логічному рівні та реалізовано об'єктно-реляційне відображення (Object-Relational Mapping), а також рішення EntityFramework та спосіб Code First Migration. Спочатку це було зроблено для створення класів, які відображають сутності майбутньої бази даних, а потім - для автоматичного створення та виконання міграції цих класів у базу даних SQL Server (Conallen, 2001).

Для реалізації бази даних Couchbase Server було застосовано аналогічний підхід як і при реалізації бази даних SQL Server. Однак, оскільки Couchbase Server є документо-орієнтованою базою даних типу NoSQL i у неї немає чітко визначеної схеми, то об'єкти класів (сутності бази) конвертуються у json-документи та зберігаються у цій базі даних без застосування міграцій чи якихось інших обмежень. Для налаштування та управління цією базою даних було використано панель адміністратора Couchbase Server (рис. 9).

Перед тим, як заповнювати базу даних відповідними документами, було виконано налаштування для Cluster (кластер) - групи фізичних вузлів, у межах яких вона може бути розгорнута. В цьому випадку було налаштовано один фізичний вузол. Також було створено Instagram Bucket (бакет) - що з термінології Couchbase документації можна перекласти як база даних. В бакеті збе- рігаються JSON-документи. Під час проектування та реалізації компонент веб-додатку відбувалося поєднання об'єктно-орієнтованого підходу програмування 3 процедурно-орієнтованим. Усі розроблені класи були задокументовані.

Потенційний користувач веб-додаток може його використовувати під управлінням будь-якої відомої операційної системи (Windows, MacOS, Linux). Він не потребує його встановлення на машині клієнта. Аби отримати доступ до нього, потрібно спочатку налаштувати його під'єднання до мережі Internet та встановити браузер для доступу до веб-додатку.

Отже, веб-додаток розроблено з використанням технології ASP.NET MVC 5, мови програмування C\# 3.0 у середовищі розробки Microsoft Visual Studio 2017, мови розмітки HTML 5, таблиць стилів CSS 3, скриптової мови програмування ECMAScript 6, системи управління реляційними базами даних Microsoft SQL Server 2016 та системи управління базами даних класу NoSQL - Couchbase Server 5.1.0. У системі реалізації веб-додатку імплементовано такі основні функціональні характеристики, як аналіз бізнес-акаунта на підставі обчислених метрик і статистик, налаштування та запуск алгоритму автоматичного виконання вподобання та коментування дописів, стеження за акаунтами в мережі Instagram. Відповідно до архітектури проектного рішення, веб-додаток реалізовано у вигляді розподіленої архітектури як на апаратному, так і на програмному рівнях для того, щоб задовольнити таку не функціональну вимогу, як його гнучкість. 


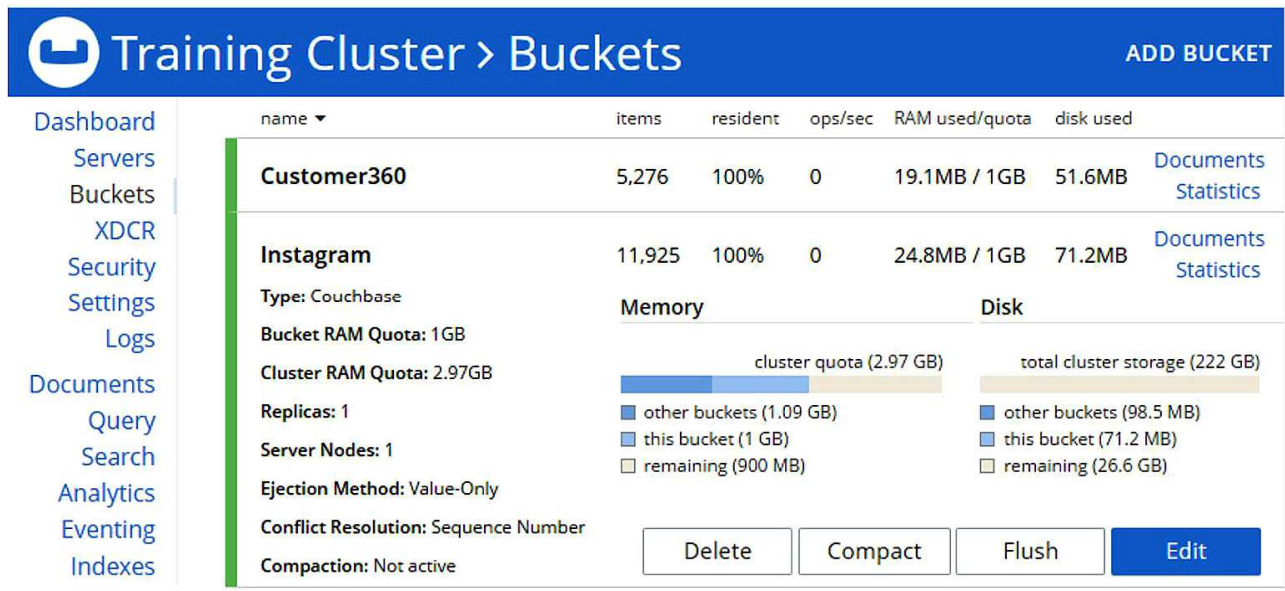

Рис. 9. Панель адміністратора СУБД Couchbase Server

Висновки. Розроблено веб-додаток, за допомогою якого можна проводити маркетинговий аналіз бізнесакаунта соціальної мережі Instagram, що дає змогу в реальному часі отримувати достовірну інформацію про поточний його стан, нарощувати аудиторію його потенційних користувачів через автоматизацію певних дій, а також уможливить формування стратегії для подальшого його просування. За результатами виконання виконаної роботи можна зробити такі висновки:

1. Встановлено потребу маркетингового аналізу соціальної мережі Instagram, що дасть змогу маркетологу на підставі отриманої інформації розробити комплекс заходів для просування бізнес-акаунта шляхом запровадження відповідних медіа-ресурсів.

2. 3'ясовано причини застосування Instagram-метрик, статистик і автоматизації дій користувача для аналізу маркетингової інформації, що дасть змогу маркетологу визначити поточний стан бізнес-акаунта i розробити стратегії для подальшого його просування.

3. Спроектовано архітектуру веб-додатку для реалізації метрик, статистик і автоматизацій дій користувача, що дало змогу розробити відповідний програмний засіб для маркетингового аналізу соціальної мережі Instagram в реальному часі, який уможливить отримання достовірної інформації про поточний стан бузнес-акаунта.

4. Розроблено структуру організації баз даних для реалізації веб-додатку, що забезпечить надійне зберігання даних, необхідних для авторизації та автоматизації дій користувача, а також обчислення відповідних метрик i статистик, підготовки певних компонент - клієнтів для доступу до цих баз даних.

5. Реалізовано веб-додаток з використанням відповідної технології та мови програмування у певному середовищі розробки, а також систему управління базами даних. У структуру реалізації веб-додатку імплементовано такі основні його функціональні характеристики, як аналіз бізнес-акаунта на підставі обчислених метрик i статистик, налаштування на автоматизацію таких дій користувача, як стеження за іншими користувачами, вподобання та коментування їхніх дописів у мережі Instagram.

\section{Перелік використаних джерел}

Active Instagram users. (2019). Number of monthly active Instagram users from January 2013 to June 2018 (In millions). Retrieved from: $\quad$ https://www.statista.com/statistics/253577/number-ofmonthly-active-instagram-users/

Ageenko, Ya. V. (2019). Website classification: types and types of Internet sites. What are the sites. Retrieved from: http://www.yanajy.com/sdelay-sam/vidy-sajtov.html. [In Russian].
Barabasi, A. L. (2002). Linked: The new science of networks. Cambridge: Perseus Publishing, $229 \mathrm{p}$.

Barnes, J. A. (1954). Class and committees in Norwegian island parish. London: School of Economics, University of London, $58 \mathrm{p}$.

Bashinskaya, I. O. (2012). Marketing communications of enterprise in social networks. Economic Sciences. Series "Economics and Management", 9(34), Vol. 1, 36-41. [In Ukrainian].

Bora, Krishna. (2018). Important Instagram Metrics. Retrieved from: https://www.campaignmonitor.com/blog/technology/2018/12/6-important-instagram-metrics-for-your-brand-with-tips-to-track-them/

Butch, G., Rumbaugh, J., \& Jacobson, A. (2000). UML language. User's manual. Moscow: DMK Publishing House, 432 p. [In Russian].

Carson, James. (2017). What is social media and how did it grow so quickly?. Retrieved from: https://www.telegraph.co.uk/technology/0/social-media-did-grow-quickly/

Chloe West. (2019). 17 Instagram stats marketers need to know for 2019. Retrieved from: https://sproutsocial.com/insights/instagramstats/

comScore. (2019). Social networks in 2011: comScore research. Retrieved from: http://cossa.ru/articles/149/11382. [In Russian].

Conallen, J. (2001). Web application development using UML. (Trans. from English). Moscow: Williams Publishing House, 288 p. [In Russian].

Danko, Yu. A. (2012). Social networks as a form of modern communication: the pros and cons. Modern society: political sciences, sociological sciences, cultural sciences, 2, 179-184. [In Ukrainian].

Grishchenko, O. F., \& Nsesheva, A. D. (2013). Social media marketing as a tool for product promotion. Marketing and Innovations Management: Sumy State University Magazine, 4, 35-48. [In Ukrainian].

Gunelius, S. (2010). 30-Minute Social Media Marketing: Step-by-step Techniques to Spread the Word About Your Business. McGrawHill, $272 \mathrm{p}$.

Illyashenko, S. M. (2011). Modern trends in the use of Internet technologies in marketing. Marketing and management of innovations, 2(4), 64-74. [In Ukrainian].

Jackson, Dominique. (2017). 6 Instagram Metrics That Truly Measure Your Efforts. Retrieved from: https://sproutsocial.com/insights/instagram-metrics/

Kindness, Joe. (2018). 7 Instagram Metrics You Should Track to Measure Performance. Retrieved from: https://agencyanalytics.com/blog/instagram-metrics-to-measure-success

Macyaszek, L. A. (2002). Requirements analysis and system design. Development of information systems using UML. Moscow: Williams Publishing House, 432 p. [In Russian].

Marketing. (2019). Marketing in social networks. Retrieved from: https://uk.wikipedia.org/wiki/Marketynh_u_sotsialnykh_merezhakh Schivinski, B., \& Dąbrowski, D. (2013). The Impact of Brand Communication on Brand Equity Dimensions and Brand Purchase Intention Through Facebook: Working Paper. Gdansk University of Technology, $20 \mathrm{p}$.

Scissons, M., Vo, J., \& Sim, H. (2014). Instagram marketing strategy: Electronic Book. FlashStock Technology Inc., 72 p. 
Sitnik, O. (2014). Visual communication in the system of compositional-graphic modeling of information portals. Pedagogical Innovations: Ideas, Realities, Prospects, 2, 87-93. [In Ukrainian].

Social network. (2019). Wikipedia. Free Encyclopedia. Retrieved from: http://ru.wikipedia.org/wiki/Sotsyalnaia set. [In Ukrainian].

Software. (2019). Hardware and Software Requirements. Retrieved from: $\mathrm{https}: / /$ docs.couchbase.com/server/4.1/install/pre-install.html.

Stelzner, M. (2012). Social Media Marketing Industry Report. How Marketers Are Using Social Media to Grow Their Businesses-Social media examiner, $42 \mathrm{p}$.
Todd Clarke. (2019). 22+ Instagram Stats That Marketers Cant Ignore This Year. Retrieved from: https://blog.hootsuite.com/instagramstatistics/

Zabastanskaya, L. A., \& Abramchuk, O. V. (2017). Social networks, their benefits and harm to human life. XLVI Scientific and Technical Conference of Vinnytsia National Technical University. Series: Social and Human Sciences, 1, 1-2. [In Ukrainian].

Yu. I. Hrytsiuk, T. P. Biletskyi

Lviv Polytechnic National University, Lviv, Ukraine

\section{WEB APPLICATION FOR MARKETING ANALYSIS} OF THE SOCIAL NETWORK INSTAGRAM

Web-based application for the marketing analysis of business accounts of the social network Instagram has been developed, which allows receiving real-time information about their current state, increasing the audience of potential users by automating certain actions, and also enables the formation of strategies for their further promotion. In the course of research we have defined the basic needs of the analysis of the social network Instagram. This enabled marketers to develop a set of measures to promote business accounts through appropriate media resources. The reasons for the use of Instagram metrics, statistics and automation of user actions to analyze marketing information are revealed. This enabled determining the parameters of the current state of the business account and developing a strategy for further advancement. Furthermore, the architecture of web application for the implementation of metrics, statistics and automation of user's actions was designed. This allowed us to develop an appropriate marketing software tool for analyzing the social network Instagram in real time. This tool provides reliable information about the current state of business account. The structure of the organization of the database to implement web application is developed as well. Databases provide secure data storage required for authentication and automation of user's actions. The data is necessary to calculate appropriate metrics and statistics, to prepare certain component - clients to access these databases. A web application is implemented using the appropriate technology and a programming language in a particular development environment, and a database management system is proposed as well. The web application structure has functional features implemented such as business account analysis based on metrics and statistics, automation settings for user's actions such as likes, comment posts and follow accounts on Instagram.

Keywords: business account; media resources; target audience; account promotion strategy; marketing information; web application architecture; implementation of metrics and statistics; automation of user's actions. 